\title{
"Inhibitory effect of Brazilian red propolis on Candida biofilms developed on titanium surfaces"
}

Loyse Martorano-Fernandes ${ }^{1}$, Yuri Wanderley Cavalcanti ${ }^{2}$ and Leopoldina de Fátima Dantas de Almeida ${ }^{2 *}$

\begin{abstract}
Background: Peri-implant inflammation resulting from the presence of Candida biofilms may compromise the longevity of implant-supported dentures. This study evaluated the inhibitory effect of Brazilian red propolis on mono-species biofilms of C. albicans (ATCC 90028) and co-culture biofilms of C. albicans (ATCC 90028) and C. glabrata (ATCC 2001), developed on titanium surfaces.

Methods: Titanium specimens were pre-conditioned with artificial saliva and submitted to biofilm formation $\left(1 \times 10^{6} \mathrm{CFU} / \mathrm{mL}\right.$ ). After $24 \mathrm{~h}$ (under microaerophilic conditions at $37^{\circ} \mathrm{C}$ ) biofilms were submitted to treatment for 10 min, according to the groups: sterile saline solution (growth control), $0.12 \%$ chlorhexidine and $3 \%$ red propolis extract. Treatments were performed every $24 \mathrm{~h}$ for 3 days and analyses were conducted $96 \mathrm{~h}$ after initial adhesion. After that, the metabolic activity (MTT assay) ( $n=12$ /group), cell viability (CFU counts) ( $n=12 /$ group) and surface roughness (optical profilometry) ( $n=6 /$ group) were evaluated. Data from viability and metabolic activity assays were evaluated by ANOVA and Tukey tests. Surface roughness analysis was determined by Kruskal Wallis e Mann Whitney tests.
\end{abstract}

Results: Regarding the mono-species biofilm, the cell viability and the metabolic activity showed that both chlorhexidine and red propolis had inhibitory effects and reduced the metabolism of biofilms, differing statistically from the growth control $(p<0.05)$. With regards the co-culture biofilms, chlorhexidine had the highest inhibitory effect $(p<0.05)$. The metabolic activity was reduced by the exposure to chlorhexidine and to red propolis, different from the growth control group $(p<0.05)$. The surface roughness (Sa parameter) within the mono-species and the co-culture biofilms statistically differed among groups $(p<0.05)$.

Conclusions: Brazilian red propolis demonstrated potential antifungal activity against Candida biofilms, suggesting it is a feasible alternative for the treatment of peri-implantitis.

Keywords: Biofilms, Candida, Peri-implantitis, Infection control

\footnotetext{
* Correspondence: leopoldinalmeida@hotmail.com

${ }^{2}$ Department of Clinic and Social Dentistry, Federal University of Paraíba,

Cidade Universitária, João Pessoa, Paraiba, Brazil

Full list of author information is available at the end of the article
}

\section{$\triangle B M C$}

(c) The Author(s). 2020 Open Access This article is licensed under a Creative Commons Attribution 4.0 International License, which permits use, sharing, adaptation, distribution and reproduction in any medium or format, as long as you give appropriate credit to the original author(s) and the source, provide a link to the Creative Commons licence, and indicate if changes were made. The images or other third party material in this article are included in the article's Creative Commons licence, unless indicated otherwise in a credit line to the material. If material is not included in the article's Creative Commons licence and your intended use is not permitted by statutory regulation or exceeds the permitted use, you will need to obtain permission directly from the copyright holder. To view a copy of this licence, visit http://creativecommons.org/licenses/by/4.0/. The Creative Commons Public Domain Dedication waiver (http://creativecommons.org/publicdomain/zero/1.0/) applies to the data made available in this article, unless otherwise stated in a credit line to the data. 


\section{Background}

Peri-implantitis is a biofilm-dependent disease, in which the presence of bacteria and fungi within peri-implant tissues results in an inflammatory response [1]. Deficient hygiene, alcohol and tobacco consumption, systemic conditions including diabetes and immunosuppression can modulate peri-implantitis [2]. Multispecies biofilms frequently involved with peri-implantitis include proteolytic bacteria, such as Porphyromonas gingivalis and Prevotella intermedia [3, 4], in association with saccharolytic bacteria (Streptococcus mutans and Streptococcus sanguinis) and fungal species (Candida sp) [2, 5, 6].

In this context, $30 \%$ of the microorganisms identified in peri-implant biofilm are fungi of the genus Candida [7]. The presence of those microorganisms, in association with deficient hygiene, can induce a harmful microenvironment, in which the multispecies communities can release toxins and by-products that makes treatment unsuccessful [8]. Therefore, some clinical procedures have been proposed, including abrasive therapies with air, water, sodium bicarbonate, citric acid, plastic curettes scraping, ultrasonic cleansing, among others $[9,10]$. However, none of those methods have obtained satisfactory results [8].

The use of topical antimicrobial agents associated with standard cleansing methods has been suggested [11]. In fact, antimicrobial mouthwash solutions are the most widespread, because it is an easy and cheap method [11]. Chlorhexidine $0.12 \%$ is considered the chemical gold standard for the treatment of peri-implantitis [12]. Although its use is recommended, using the therapy for a prolonged period of time has adverse effects, such as desquamated lesions, teeth and mucosal staining, loss of taste and dry mouth [13]. Therefore, the search for agents that present antimicrobial potential; with fewer side effects has been observed. Bioactive molecules and natural products have been investigated with regards to their potential to interfere with the adhesion and proliferation of microorganisms [14, 15].

In this context, the Brazilian red propolis has demonstrated an inhibitory effect against mono-species biofilm of $C$. albicans in a similar manner to that of chlorhexidine [16-18]. Propolis is a natural resin produced by bees [19], with antitumor, anti-oxidative and antimicrobial activities [20]. Its effects are due to the presence of flavonoids within the extracts, such as quercetin, rutin and kaempferol [21]. Thereby, Brazilian red propolis is suggested for treatment of biofilm-dependent diseases, in both forms of mouthwash and denture cleanser.

However, the use of red propolis extract has not been evaluated under peri-implantitis-like microenvironment. Thus, the aim of this study was to evaluate the inhibitory effect of the Brazilian red propolis on mono-species biofilms of C. albicans (ATCC 90028) and co-culture biofilms of C. albicans (ATCC 90028) and C. glabrata (ATCC 2001), developed on titanium surfaces. Our findings suggest that extract may be used for peri-implantitis disease, but cytotoxic effects could be a limitation for clinical applications.

\section{Methods}

\section{Microbial strains and growth conditions}

Strains of C. albicans (ATCC 90028) and C. glabrata (ATCC 2001) were cultivated aerobically on Sabouraud Dextrose (Merck KGaA, Germany) agar at $37^{\circ} \mathrm{C}$. Cell suspensions were grown in RPMI 1640 (Inlab diagnóstica, Brazil) during $24 \mathrm{~h}$ at $37^{\circ} \mathrm{C}$. Before experiments, cells were centrifuged ( $5000 \mathrm{~g}$ for $5 \mathrm{~min}$ ), washed twice with sterile saline, and suspended in RPMI 1640 medium. Suspensions were standardized at $\mathrm{OD}_{600}=1.0$ $\left(1 \times 10^{6}\right.$ cells $\left./ \mathrm{mL}\right)$ (LGL Scientific 0741/16, Brazil), based in experiments described previously with some adaptations [22].

\section{Specimens' preparation}

Commercially pure titanium discs $(1.3 \times 0.2 \mathrm{~cm})$ were prepared and polished in a barrel with abrasive paste and ceramic particles for $8 \mathrm{~h}$ [23]. Subsequently, they were cleaned with $70 \%$ alcohol (v/v) and sterilized by autoclave at $121{ }^{\circ} \mathrm{C}$ for $15 \mathrm{~min}$. Specimens were allocated into three different groups $(n=12$ /group). Hydroalcoholic extract of Brazilian red propolis at $3 \%$ concentration $(\mathrm{v} / \mathrm{v})$ was used as experimental group. Chlorhexidine at $0.12 \%$ (Colgate-Palmolive, São Paulo, Brazil) was used as positive control, whilst sterile saline solution was used as growth control.

\section{Salivary pellicle formation and biofilm development}

Initially, salivary pellicle was induced by immersing specimens in artificial saliva composed of $1 \%$ carboxymethyl $(\mathrm{w} / \mathrm{v}) ; 0.0084 \%$ sodium chloride $(\mathrm{w} / \mathrm{v}) ; 0.12 \%$ potassium chloride (w/v); $0.0342 \%$ potassium phosphate $(\mathrm{w} / \mathrm{v})$; $0.0146 \%$ calcium chloride (w/v), and $0.052 \%$ magnesium chloride (w/v) [24] and incubated at $37^{\circ} \mathrm{C}$ for $60 \mathrm{~min}$. Afterwards, the specimens with salivary pellicle were transferred to 24-well plates.

Microbial cell suspensions in RPMI 1640 medium $(1 \times$ $10^{6}$ cells $\left./ \mathrm{mL}\right)$ were added together with RPMI 1640 medium (10x dilution) to generate mono-species biofilm of C.albicans and co-culture biofilm of Calbicans and C.glabrata on the surface of titanium discs. Plates were then was incubated for $24 \mathrm{~h}$ at $37^{\circ} \mathrm{C}$, under microaerobic conditions. The micro-aerobic atmosphere was generated by using an anaerobic jar with a candle, which reduced the presence of oxygen, similar to a periimplant-like environment. After $24 \mathrm{~h}$ incubation, unattached cell suspension was aspirated. Specimens were then exposed to substances and washed twice with 
saline. Culture medium was renewed every $24 \mathrm{~h}$, after each treatment.

\section{Expositions to tested substances}

The hydroalcoholic extract of Brazilian red propolis (Laboratory Edimel, Paraíba, Brazil) was obtained at initial concentration of $30 \%(\mathrm{w} / \mathrm{v})$ and diluted in sterile saline to yield concentration of $3 \%(\mathrm{w} / \mathrm{v})$, as determined previously [16]. The sterile saline was used as growth control of biofilm. The specimens were exposed to the solutions at $24 \mathrm{~h}, 48 \mathrm{~h}$ and $72 \mathrm{~h}$ from the start of biofilm formation. In each exposition episode, specimens were immersed in tested substances and remained in contact with them for $10 \mathrm{~min}$. After exposition, specimens were washed twice with sterile saline solution and the culture medium was renewed, followed by incubation under micro-aerobic conditions at $37^{\circ} \mathrm{C}$. Analyses were made at $96 \mathrm{~h}$ (4 days).

\section{Cell viability analysis}

For cell viability analysis, the specimens were transferred to tubes containing $1.0 \mathrm{~mL}$ sterile saline solution, submitted to agitation in a vortex for $60 \mathrm{~s}$, followed by serial dilution of the aliquots to determine the number of viable microorganisms $\left(10^{-1}\right.$ up to $\left.10^{-6}\right)$.

Aliquots of $10 \mu \mathrm{l}$ of each serial dilution were seeded in triplicate on Sabouraud dextrose agar. The plates were then incubated at $37^{\circ} \mathrm{C}$ for $48 \mathrm{~h}$ for later viable colony counts reading. The number of viable cells was counted and the values multiplied by the serial dilution. Data was expressed in colony forming unit per milliliter $(\mathrm{CFU} / \mathrm{mL})$.

\section{Cell metabolism assay}

Cell metabolism was analyzed by means of MTT (methyl-tretrazolium salt) assay. For this, specimens were incubated with $600 \mu \mathrm{L}$ of culture medium containing $10 \%$ of MTT (Sigma-Aldrich, St. Louis, MO, USA). The salt was oxidized by the SDH (succinate dehydrogenase) enzyme present in the respiratory chain of the fungi, and then used to determine the viable cell metabolism. Specimens were incubated at $37^{\circ} \mathrm{C}$ for $3 \mathrm{~h}$ in the presence of MTT salt and the system was protected from the light. After this, the supernatant was removed and $600 \mu \mathrm{L}$ isopropanol acid $(6 \mathrm{~N}-\mathrm{HCl})$ (Sigma-Aldrich, St. Louis, MO, USA) was inserted, followed by sample homogenization. The supernatant was collected and its absorbance analyzed under spectrophotometer at $570 \mathrm{~nm}$ (LGL Scientific 0741/16, Brazil).

\section{Surface roughness}

The surface roughness of the biofilms ( $n=6$ /group) was determined by means of Profilometer analysis (CCI MP, Taylor Hobson, England). This analysis aimed to assess the presence and complexity of biofilms. More complex and thicker biofilms also present greater surface roughness. The biofilms were fixed in an aqueous solution of 2.5\% glutaraldehyde (Sigma-Aldrich, St. Louis, MO, USA), at $4{ }^{\circ} \mathrm{C}$ for $24 \mathrm{~h}$, and dehydrated at room temperature through increasing cycles of ethanol (50 to $100 \%)$. Surface roughness measurements $(\mu \mathrm{m})$ were taken at two distinct points of the specimen, under $20 \times$ magnification, considering the measurement standards xy $(1024 \times 1024$ pixels $)$, xyz $(512 \times 512$ pixels $)$ and $\mathrm{z}$ $(256 \times 256$ pixels). The speed of $3 \times$ was established, being the Surface Roughness Area (Sa) explored. Specimens without any biofilm (baseline) on the surface were also evaluated and used as reference for the analysis of developed biofilms.

\section{Data analysis}

Data from viability, metabolic activity and surface roughness anslyses were evaluated with regards their normality and homocedasticity. Logarithmic transformation of viable cell counts was performed for statistical purposes. Statistical analysis was performed by means of one-way analysis of variance (ANOVA) and Tukey tests. All analyses were performed with 5\% significance and power of $80 \%$.

\section{Results}

Cell viability determined that both chlorhexidine and red propolis extract had inhibitory effects on the proliferation of mono-species biofilms of C. albicans, differing statistically from the growth control $(p<0.05)$ (Fig.1a). With regards to the metabolic activity of biofilms, both chlorhexidine and red propolis reduced the metabolism of mono-species biofilms of $C$. albicans, differing statistically from the growth control $(p<0.05)$ (Fig.1b). The results of viability and metabolic activity in monospecies biofilms of $C$. albicans showed that Brazilian red propolis extract presented similar effect to that observed for chlorhexidine $(p>0.05)$.

Within the co-culture biofilms, chlorhexidine had the highest inhibitory effect, differing from the other substances $(p<0.05)$ (Fig.2a). Although Brazilian red propolis extract did not inhibited co-cultures biofilm as chlorhexidine, there was a considerable inhibitory effect, statistically different from the growth control $(p<0.05)$. The exposure to chlorhexidine and to Brazilian red propolis extract reduced significantly the metabolism of co-cultured biofilms (Fig. 2b) $(p<0.05)$.

The surface roughness is indicative of the presence of biofilm. In our study, the baseline (specimens without biofilm) was used for comparison with all treatment groups. Within mono-species biofilms of C. albicans, the surface roughness of specimens treated with chlorhexidine and red propolis extract did not differ from baseline 


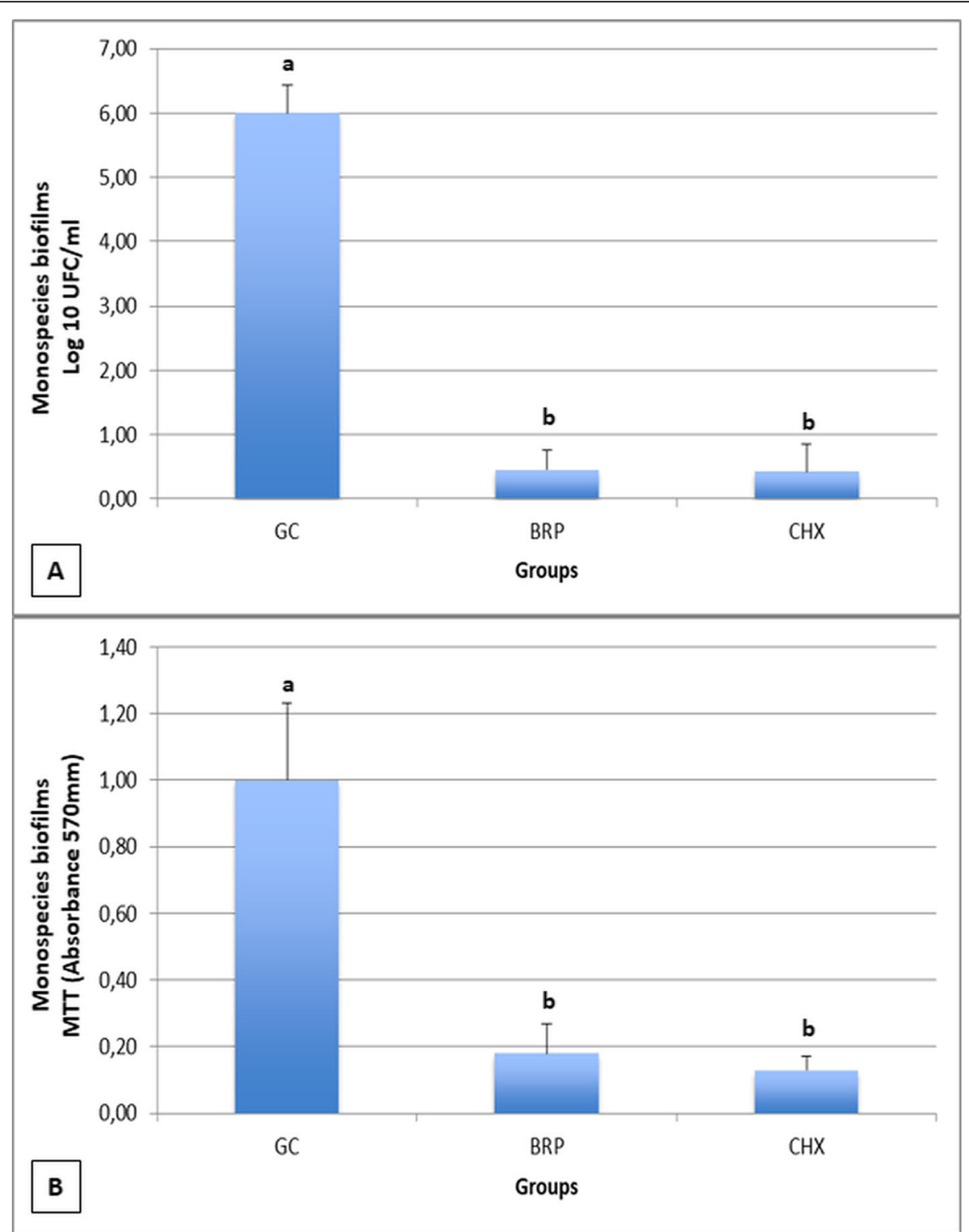

Fig. 1 a Cell viability of biofilms (UFC/mL). Biofilms of C. albicans exposed to saline were considered as growth control. Columns represent averages and error bars represent standard deviations $(n=12)$. b Cell metabolism by the MTT assay. Biofilms of $C$. albicans exposed to saline were considered as growth control. Columns represent averages and error bars represent standard deviations $(n=12)$. Groups identified with the same letter do not differ statistically (Tukey, $p>0.05$ ). GC: growth control; BRP: Brazilian red propolis; CHX: chlorhexidine

$(p>0.05)$, but statistically differed from control $(p<$ 0.05 ) (Fig. 3). This suggests treatments significantly reduced the presence of biofilm. With regards to coculture biofilms, specimens treated with chlorhexidine did not differ from baseline $(p>0.05)$, but statistically differed from control and red propolis extract $(p<0.05)$ (Fig. 4). This suggests red propolis extract was less effective than chlorhexidine within co-culture biofilms.

\section{Discussion}

Different treatment protocols for peri-implantitis have been studied, including chemical and mechanical intervention strategies $[10,25,26]$. Considering the increasing use of natural products, we have show that Brazilian red propolis hydroalcoholic extract have inhibitory effect on mono-species biofilms of Candida albicans and co-culture biofilms of $C$. albicans and $C$. glabrata developed on titanium surfaces. Results from this study show that Brazilian red propolis extract has similar antimicrobial activity of chlorhexidine-based mouthwash. Our findings may be useful for the biofilm control of implant-supported dentures.

The use of antimicrobial topical agents may be effective and well-disseminated method to prevent biofilm 


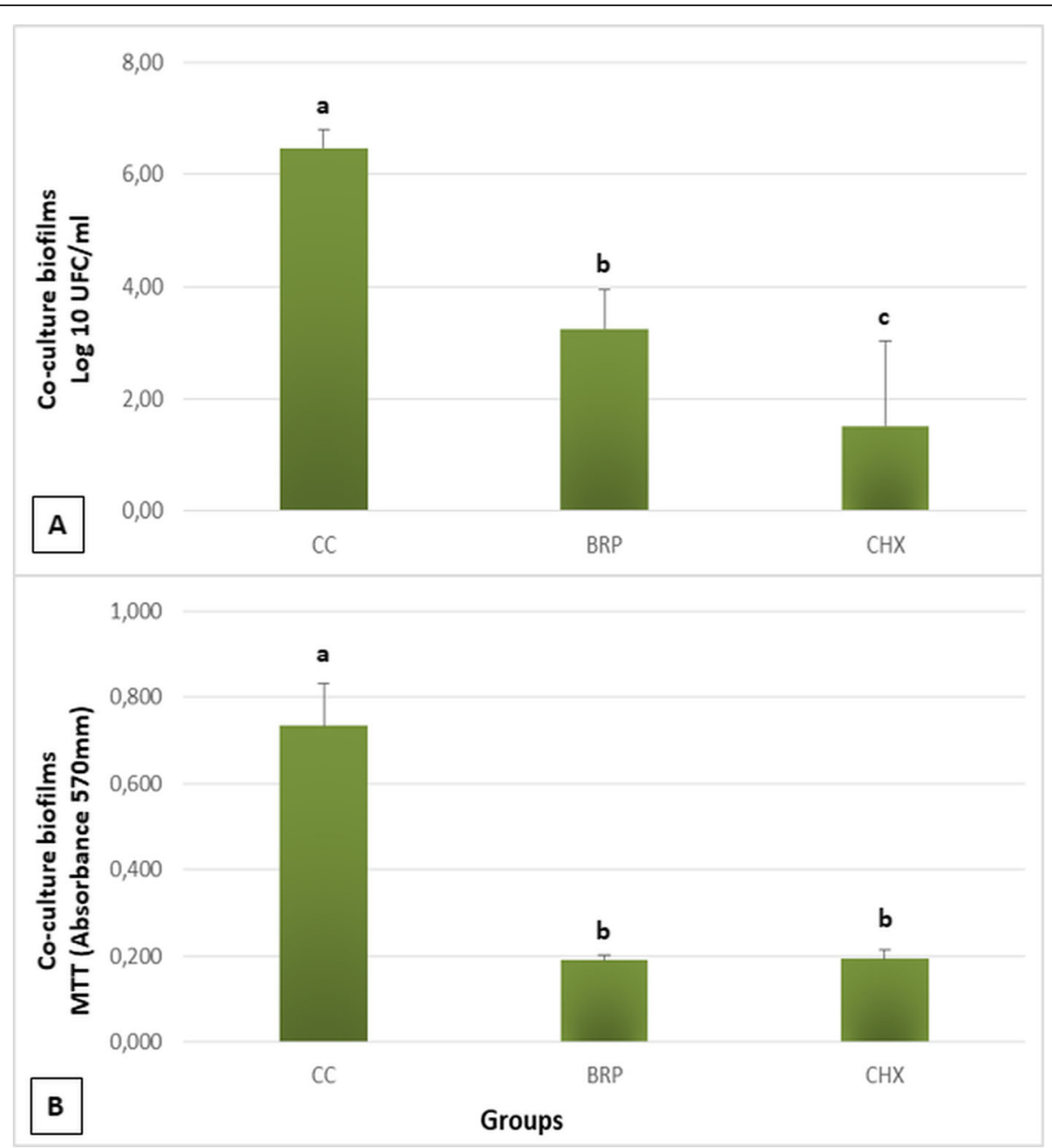

Fig. 2 a Cell viability of biofilms (UFC/mL). Biofilms of C. albicans and C. glabrata exposed to saline were considered as growth control. Columns represent averages and error bars represent standard deviations $(n=12)$. b Cell metabolism by the MTT assay. Biofilms of $C$. albicans and $C$. glabrata exposed to saline were considered as growth control. Columns represent averages and error bars represent standard deviations ( $n=12)$. Groups identified with the same letter do not differ statistically (Tukey, $p>0.05$ ). GC: growth control; BRP: Brazilian red propolis;

CHX: chlorhexidine

accumulation, especially for regions that are difficult to clean, such as peri-implant sites. Although chlorhexidine have been extensively used for biofilm control, its toxic potential to the mucosa contra-indicates its use for prolonged periods [13]. Brazilian red propolis hydroalcoholic extract at $3 \%$ has demonstrated a cytotoxic activity around 43\% against fibroblasts monolayers (L-929) [16]. It is worth emphasizing that the implementation of an antimicrobial therapy must modulate the cell proliferation, so that when it debilitates the infection, there must not be great damage to the subjacent tissue. For this reason, Brazilian red propolis extract were selected according to the minimum inhibitory concentration (MIC) previously reported within the literature [16].

The 3\% red propolis hydroalcoholic extract demonstrate an inhibitory effect on mono-species biofilm of $C$. albicans in a manner similar to that of chlorhexidine. Propolis is a natural resin produced by bees [19], and has a varied chemical composition depending on to geographic location, bee species and season of the year [27]. Diverse formulations of propolis have been evaluated with regards their antitumoral, anti-oxidative and antimicrobial activity [20], being these effects acknowledged to flavanoids present within the extracts [21]. Flavonoids also have anti-inflammatory activity, which is an appropriate characteristic for a mouthwash [28]. Further studies however are necessary to assess toxicity to cell lines and tissue culture, in order to give support to future clinical investigations [29].

The antimicrobial activity of Brazilian red propolis, in particular, has been determined against microorganisms such as Staphylococcus spp, Actinomyces naeslundii and 


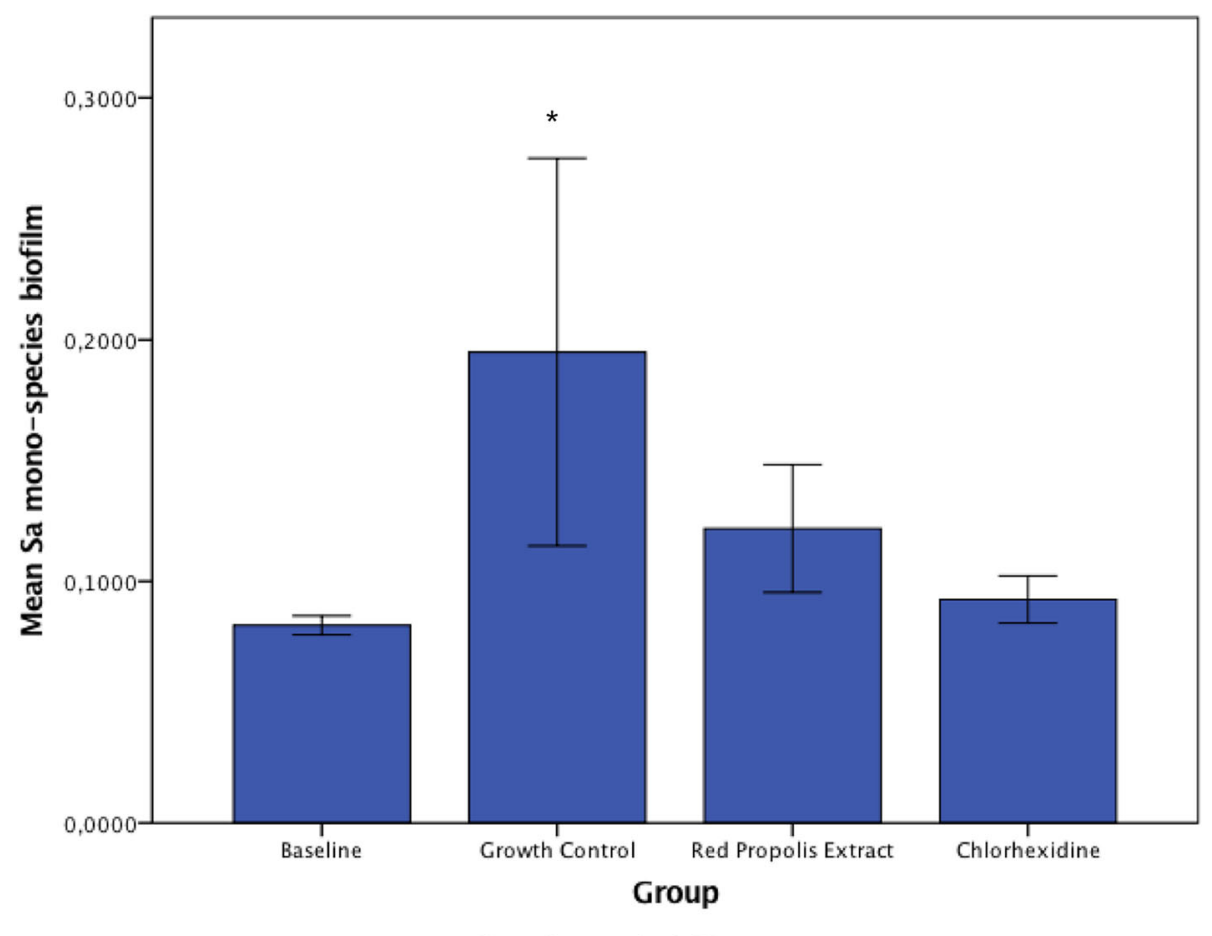

Error Bars: $+/-1$ SD

Fig. 3 Comparison of Surface Roughness Area (Sa) among mono-species biofilms of C. albicans treated with the substances ( $n=6 / g r o u p)$. Asterisk shows that growth control presented significantly higher surface roughness compared to other groups $(p<0.05)$. This is suggestive that chlorhexidine and red propolis extract removed most of biofilm, similarly to clean (baseline) specimens

gram-negative, such as Pseudomonas aeruginosa and Salmonella typhimurium [20, 30]. Moreover, their inhibitory activity has been reported against planktonic cultures of Streptococcus mutans, Streptococcus sobrinus, Staphylococcus aureus, Actinomyces naeslundii [17, 18]. We observed that the cell viability $(\mathrm{CFU} / \mathrm{mL})$ in monospecies biofilms of $C$. albicans was affected by exposure to the $3 \%(\mathrm{w} / \mathrm{v})$ red propolis hydroalcoholic extract. However, the red propolis extract didn't demonstrate the same efficacy against co-culture biofilms. Probably, the potential effect of the Brazilian red propolis extract would be superior in less complex biofilms with lower capacity for cell adhesion and proliferation, and therefore with greater transport of antimicrobial substances along the water channels and extracellular matrix.

Popular medicine has used propolis extract to treat throat infections and many commercial products are available nowadays varying their concentration from 10 to $30 \%(\mathrm{w} / \mathrm{v})$. In the present study, we have used a concentration equivalent to $10 \times$ dilution of a $30 \%(\mathrm{w} / \mathrm{v})$ commercial hydroalcoholic extract, which could be used to prepare a homemade mouthwash. Therefore, it should be considered that the effect evaluated in the present study consisted of a diluted extract available commercially, or a possible dilution in the mouth after swallowing ( $3 \times$ dilution of a $10 \%(w / v)$ product).
Our findings corroborate those of authors who have demonstrated the inhibitory effect of this substance against species of Candida in patients with periodontitis [31, 32], and using in a multispecies biofilm of Staphylococcus aureus, Staphylococcus epidermides, Pseudomonas aeruginosa, Candida albicans, Candida tropicalis and Cryptococcus neoformans [31]. Although a promising antimicrobial activity has been demonstrated for Brazilian red propolis extract, further studies are necessary for identifying which of the phytochemicals are involved with the antimicrobial activity.

The concentration of flavonoids such as quecertin, rutin and kaempferol can vary according to the period of collection of crude material. Based on that, variations on the antimicrobial activity of red propolis extract might be observed [19]. However, there are no findings that could confirm the same results against Candida species. Although clinical trials are necessary, this substance was shown to be an effective alternative for the treatment of Candida infections. In this study, the Brazilian red propolis hydroalcoholic extract at $3 \%$ concentration presented similar results to that observed for chlorhexidine, for both mono-species of C. albicans and co-culture biofilms of $C$. albicans and C. glabrata. Literature has reported that red propolis extract also has anti-oxidant effects, similarly to green propolis extracts, depending 


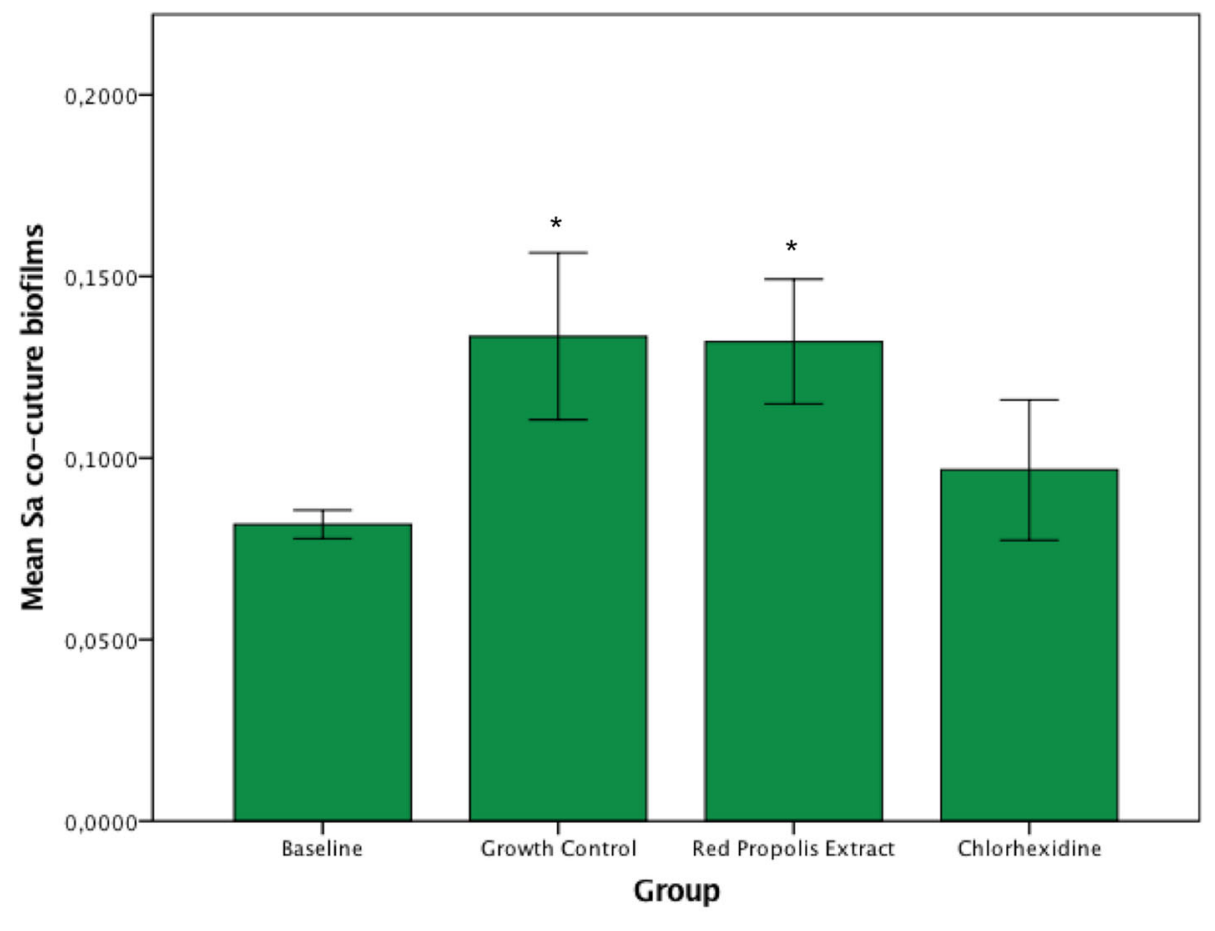

Error Bars: +/- 1 SD

Fig. 4 Comparison of Surface Roughness Area ( $\mathrm{Sa}$ ) among co-culture biofilms treated with the substances ( $n=6 /$ group). Asterisks show that growth control and red propolis extract presented significantly higher surface roughness compared to other groups $(p<0.05)$. This is suggestive that chlorhexidine removed most of biofilm, similarly to clean (baseline) specimens

on concentration [33]. The bioactivity of Brazilian red propolis extract by using in vitro models of oral epithelium is strongly suggested.

The surface roughness observed for biofilms treated with red propolis hydroalcoholic and chlorhexidine suggests that these treatments had equivalent efficacy. Stronger evidence of similar efficacy of red propolis and chlorhexidine is due to the reduction of cell viability and metabolic activity of biofilms. The presence of remaining biofilms even after successive processes of cleaning with antimicrobial solutions is an aspect that has been observed in various studies [34-36]. Based on that, the literature has demonstrated that chemical cleansing solutions are not completely efficient in sterilizing surfaces; however, they contribute to reducing the microbial load. Under the conditions of the present study, the Brazilian red propolis extract reduced the Candida biofilm load and activity. This shows a positive aspect because there is lower risk of causing biofilm imbalance in vivo, with proliferation of opportunist species. Therefore, we suggest that the daily cleansing protocols evaluated in the present manuscript contribute to the oral hygiene of individuals with dental implants.

Future studies must consider an even more complex multispecies biofilm, with the involvement of other microbial species related to the etiology of periimplantitis. However, to evaluate the effect of antimicrobial agents, the composition of multispecies biofilms must consider the absence of antagonistic relations among the microorganisms. Therefore, under the conditions of the present study, the authors used a co-culture biofilm with proven synergistic behavior among species [37]. Evaluation of a mixed biofilm with antagonist species could generate a false impression of the efficacy of the antimicrobial solutions evaluated. Lastly, analysis of the toxicity of the substance is still necessary for making it feasible to design clinical studies.

Peri-implant biofilm was mimicked by cell adhesion to titanium surfaces, using a previously described methodology [23, 38]. In spite of being an in vitro model, the comparison between mono-species of $C$. albicans and co-culture biofilms of $C$. albicans and C. glabrata allowed the authors to evaluate potential of chemical agents involved in the control of peri-implantitis biofilms. Ideally, such agents may have diffusion capacity along the extracellular matrixes and have an antimicrobial effect against a larger number of cells. Therefore, Brazilian red propolis hydroalcoholic demonstrated these properties, confirming the potential use of this substance for the treatment of peri-implantitis. 


\section{Conclusion}

Brazilian red propolis demonstrated antifungal activity against Candida albicans and Candida glabrata, suggesting it to be an alternative for the treatment of periimplantitis. The results of this study may direct further investigations into the use of this natural substance. Future studies should explore these antimicrobial effect in a complex biofilm and in vivo.

\section{Abbreviations}

ATCC: American Type Culture Collection; CFU/mL: Colony forming unit per milliliter; MTT: Methyl-tretrazolium salt; SDH: Succinate dehydrogenase; Sa: Surface roughness area; MIC: Minimum inhibitory concentration

\section{Acknowledgements}

Not applicable.

\section{Authors' contributions}

LFDA and YWC contributed equally to this manuscript. YWC and LFDA designed the study, supervised the experiments, inspected the data analyses, and revised the manuscript; LMF performed the experiments, drafted the manuscript and peformed data analysis. All authors read and approved the final manuscript.

\section{Funding}

The authors would like to thank you the Conselho Nacional de Desenvolvimento Científico e Tecnológico - Brasil (CNPq) - for the scholarship provided to the first author.

\section{Availability of data and materials}

The datasets used and/or analysed during the current study are available from the corresponding author on reasonable request.

\section{Ethics approval and consent to participate}

Not applicable.

\section{Consent for publication}

Not applicable.

\section{Competing interests}

The authors declare that they have no competing interests.

\section{Author details}

${ }^{1}$ Postgraduate Program in Dentistry, Federal University of Paraíba, Cidade Universitária, João Pessoa, Paraiba, Brazil. ${ }^{2}$ Department of Clinic and Social Dentistry, Federal University of Paraíba, Cidade Universitária, João Pessoa, Paraiba, Brazil.

Received: 21 June 2019 Accepted: 11 March 2020

Published online: 03 April 2020

\section{References}

1. Bürgers R, Hahnel S, Reichert TE, Rosentritt M, Behr M, Gerlach T, Handel G, Gosau M. Adhesion of Candida albicans to various dental implant surfaces and the influence of salivary pellicle proteins. 2010. https://doi.org/10.1016/j. actbio.2009.11.003

2. Rakic M, Galindo-Moreno P, Monje A, Radovanovic S, Wang HL, Cochran D, Sculean A, Canullo L. How frequent does peri-implantitis occur? A systematic review and meta-analysis. Clin Oral InvestigClin Oral Investig. 2018. https://doi.org/10.1007/s00784-017-2276-y.

3. Waal YC, Eijsbouts HV, Winkel EG, Winkelhoff AJ. Microbial characteristics of Peri-Implantitis : a case-control study. J PeriodontolJ Periodontol. 2017;88(2):209-17

4. Pérez-Chaparro PJ, Duarte PM, Shibli JA, Montenegro S, Lacerda Heluy S, Figueiredo LC, Faveri M, Feres M. The current weight of evidence of the microbiological profile associated with Peri-Implantitis : a systematic review. J PeriodontolJ Periodontol. 2016. https://doi.org/10.1902/jop.2016.160231.
5. Canullo L, Peñarrocha-Oltra D, Covani U, Rossetti PH. Microbiologic and Clinical Findings of Implants in Healthy Condition and with Peri-Implantitis. Int J Oral Maxillofac Implants. 2015. https://doi.org/10.11607/jomi.3947.

6. Dabdoub SM, Tsigarida AA, Kumar PS. Patient specific analysis of periodontal and Peri-implant microbiomes. J Dent ResJ Dent Res. 2013. https://doi.org/10.1177/0022034513504950.

7. Schwarz F, Becker K, Rahn S, Hegewald A, Pfeffer K, Henrich B. Real-time $P C R$ analysis of fungal organisms and bacterial species at peri-implantitis sites. Int J Implant Dent. 2015;1(1):9.

8. Htet M, Madi M, Zakaria O, Miyahara T, Xin W, Lin Z, Aoki K, Kasugai S. Decontamination of anodized implant surface with different modalities for Peri-Implantitis Treatment : lasers and mechanical debridement with citric acid. J PeriodontolJ Periodontol. 2016. https://doi.org/10.1902/jop. 2016.150615.

9. Ramanauskaite A, Juodzbalys G. Diagnostic Principles of Peri-Implantitis : a Systematic Review and Guidelines for Peri-Implantitis Diagnosis Proposal. J Oral Maxillofac Res. 2016;7(3):e8.

10. Karimi MR, Hasani A, Khosroshahian S. Efficacy of Antimicrobial Photodynamic Therapy as an Adjunctive to Mechanical Debridement in the Treatment of Peri-implant Diseases: A Randomized Controlled Clinical Trial. J Lasers Med Sci. 2016. https://doi.org/10.15171/jlms.2016.24.

11. Suárez-López Del Amo F, Yu SH, Wang HL. Non-Surgical Therapy for PeriImplant Diseases: a Systematic Review. J Oral Maxillofac Res. 2016;7(3):e13.

12. Kadkhoda Z, Amarlu Z, Eshraghi S, Samiei N. Antimicrobial effect of chlorhexidine on Aggregatibacter actinomycetemcomitans biofilms associated with peri-implantitis. J Dent Res Dent Clin Dent Prospects. 2016 https://doi.org/10.15171/joddd.2016.028.

13. Menezes KM, Fernandes-Costa AN, Silva-Neto RD, Calderon PS, Gurgel BC. Efficacy of $0.12 \%$ Chlorhexidine Gluconate for Non-Surgical Treatment of Peri-Implant Mucositis. J PeriodontolJ Periodontol. 2016:87(11):1305-13.

14. Lacet GSF, Pérez ALAL, Rocha IM, Pinheiro MA, Castro RD, Carlo HL, Lima EO, Castellano LR. Does scientific evidence for the use of natural products in the treatment of Oral candidiasis Exist? A systematic review. Evid Based Complement Alternat MedEvidence-Based Complementary and Alternative Medicine. 2015. https://doi.org/10.1155/2015/147804

15. Girardot M, Imbert C. Natural sources as innovative solutions against fungal biofilms. Adv Exp Med BiolAdv Exp Med Biol. 2016. https://doi.org/10.1007/ 5584_2016_12.

16. Martins ML, Leite KLF, Pacheco-Filho EF, Pereira AFM, Romanos MTV, Maia LC, Fonseca-Gonçalves A, Padilha WWN, Cavalcanti YW. Efficacy of red própolis hydro-alcoholic extract in controlling Streptococcus mutans biofilm build-up and dental enamel demineralization. Arch Oral BiolArch Oral Biol. 2018. https://doi.org/10.1016/j.archoralbio.2018.05.017.

17. Oldoni TLC, Cabral ISR, Regitano d'Arce MAB, Rosalen PL, Ikegaki M, Nascimento AM, Alencar SM. Isolation and analysis of bioactive isoflavonoids and chalcone from a new type of Brazilian propolis. Sep Purif TechnolSeparation and Purification Technology. 2011;77(2):208-13.

18. Bueno-Silva B, Alencar SM, Koo H, Ikegaki M, Silva GV, Napimoga MH, Rosalen PL. Anti-inflammatory and antimicrobial evaluation of neovestitol and vestitol isolated from Brazilian red propolis. J Agric Food ChemJ Agric Food Chem. 2013. https://doi.org/10.1021/jf305468f.

19. Jovito VC, Freires IA, Almeida LFD, Moura D, Castro RD, Paulo MQ, LeiteCavalcanti A. Activity of in vitro forms of dentifrices containing the hydroalcoholic extract of the ripe fruit of Eugenia uniflora L. (Surinam cherry) on cariogenic bacteria. Acta Odontol Latinoam. 2011;24(1):41-6.

20. Alencar SM, Oldoni TL, Castro ML, Cabral IS, Costa-Neto CM, Cury JA, Rosalen PL, Ikegaki M. Chemical composition and biological activity of a new type of Brazilian propolis: Red propolis. J Ethnopharmacol. 2007; 113(2):278-83.

21. Sawaya AC, Palma AM, Caetano FM, Marcucci MC, da Silva Cunha IB, Araujo CE, Shimizu MT. Comparative study of in vitro methods used to analyse the activity of propolis extracts with different compositions against species of Candida. Lett Appl MicrobiolLett Appl Microbiol. 2002;35(3):203-7.

22. Tati S, Davidow P, McCall A, Hwang-Wong E, Rojas IG, Cormack B, Edgerton M. Candida glabrata binding to Candida albicans hyphae enables its development in Oropharyngeal candidiasis. PLoS PathogPLoS Pathog. 2016 Mar 30;12(3):e1005522. https://doi.org/10.1371/journal.ppat.1005522.

23. Cavalcanti YW, Wilson $M$, Lewis M, Del-Bel-Cury AA, da Silva WJ, Williams DW. Modulation of Candida albicans virulence by bacterial biofilms on titanium surfaces. Biofouling. 2016. https://doi.org/10.1080/ 08927014.2015 .1125472 
24. Amaechi BT, Higham SM, Edgar WM. Techniques for the production of dental eroded lesions in vitro. J Oral RehabilJ Oral Rehabil. 1999;26(2): 97-102.

25. Carcuac O, Derks J, Charalampakis G, Abrahamsson I, Wennström J, Berglundh T. Adjunctive systemic and local antimicrobial therapy in the surgical treatment of Peri-implantitis : a randomized controlled clinical trial. J Dent ResJ Dent Res. 2015. https://doi.org/10.1177/0022034515601961.

26. Machtei EE, Frankenthal S, Levi G, Elimelech R, Shoshani E, Rosenfeld O, Tagger-Green N, Shlomi B. Treatment of peri-implantitis using multiple applications of chlorhexidine chips: a double-blind, randomized multiCentre clinical trial. J Clin PeriodontolJ Clin Periodontol. 2012. https://doi. org/10.1111/jcpe.12006.

27. Neto RMS, Tintino SR, da Silva ARP, Costa MDS, Boligon AA, Matias EFF, de Queiroz BV, Menezes IRA, Melo Coutinho HD. Seasonal variation of Brazilian red propolis : Antibacterial activity, synergistic effect and phytochemical screening. Food Chem ToxicolFood Chem Toxicol. 2017. https://doi.org/10. 1016/j.fct.2017.03.052.

28. Orsatti CL, Missima F, Pagliarone AC, Bachiega TF, Búfalo MC, Araújo JP Jr, Sforcin JM. Propolis immunomodulatory action in vivo on toll-like receptors 2 and 4 expression and on pro-inflammatory cytokines production in mice. Phytother ResPhytother Res. 2010. https://doi.org/10.1002/ptr.3086.

29. Oyemitan IA, Elusiyan CA, Onifade AO, Akanmu MA, Oyedeji AO, McDonald AG. Neuropharmacological profile and chemical analysis of fresh rhizome essential oil of Curcuma longa (turmeric) cultivated in Southwest Nigeria. Toxicol RepToxicol Rep. 2017. https://doi.org/10.1016/j.toxrep.2017.07.001.

30. Righi AA, Alves TR, Negri G, Marques LM, Breyer H, Salatino A. Brazilian red propolis : unreported substances, antioxidant and antimicrobial activities. J Sci Food AgricJ Sci Food Agric. 2011. https://doi.org/10.1002/jsfa.4468.

31. Siqueira AB, Rodriguez LR, Santos RK, Marinho RR, Abreu S, Peixoto RF, Gurgel BC. Antifungal activity of propolis against Candida species isolated from cases of chronic periodontitis. Braz Oral Res. 2015. https://doi.org/10. 1590/1807-3107BOR-2015.vol29.0083.

32. Lopez BG, de Lourenço CC, Alves DA, Machado D, Lancellotti M, Sawaya AC. Antimicrobial and cytotoxic activity of red propolis : an alert for its safe use. J Appl MicrobiolJ Appl Microbiol. 2015. https://doi.org/10.1111/jam.12874.

33. Machado CS, Mokochinski JB, TO L, Oliveira FCE, Cardoso MV, Ferreira RG, Sawaya ACHF, Ferreira AG, Pessoa C, Cuesta-Rubio O, Monteiro MC, Campos MS, Torres YR. Comparative Study of Chemical Composition and Biological Activity of Yellow, Green, Brown, and Red Brazilian Propolis. Evid Based Complement Alternat MedEvidence-Based Complementary and Alternative Medicine. 2016. https://doi.org/10.1155/2016/6057650.

34. Almeida LFD, Paula JF, Almeida RV, Williams DW, Hebling J, Cavalcanti YW. Efficacy of citronella and cinnamon essential oils on Candida albicans biofilms. Acta Odontol ScandActa Odontol Scand. 2016. https://doi.org/10. 3109/00016357.2016.1166261

35. Faot F, Cavalcanti YW, Mendonça MD, Pinto LR, da Silva WJ, Cury AA. Efficacy of citric acid denture cleanser on the Candida albicans biofilm formed on poly(methyl methacrylate): effects on residual biofilm and recolonization process. BMC Oral Health. 2014. https://doi.org/10.1186/14726831-14-77.

36. Freitas-Fernandes FS, Cavalcanti YW, Ricomini Filho AP, Silva WJ, Del Bel Cury AA, Bertolini MM. Effect of daily use of an enzymatic denture cleanser on Candida albicans biofilms formed on polyamide and poly (methyl methacrylate) resins: an in vitro study. J Prosthet DentJ Prosthet Dent. 2014. https://doi.org/10.1016/j.prosdent.2014.07.004.

37. Gomes PN, da Silva WJ, Pousa CC, Narvaes EA, Del Bel Cury AA. Bioactivity and cellular structure of Candida albicans and Candida glabrata biofilms grown in the presence of fluconazole. Arch Oral Biol. 2011. https://doi.org/ 10.1016/j.archoralbio.2011.04.006.

38. Drago L, Bortolin M, De Vecchi E, Agrappi S, Weinstein RL, Mattina R, Francetti L. Antibiofilm activity of sandblasted and laser-modified titanium against microorganisms isolated from peri-implantitis lesions. J ChemotherJ Chemother. 2016. https://doi.org/10.1080/1120009X.2016.1158489.

\section{Publisher's Note}

Springer Nature remains neutral with regard to jurisdictional claims in published maps and institutional affiliations.

\section{Ready to submit your research? Choose BMC and benefit from:}

- fast, convenient online submission

- thorough peer review by experienced researchers in your field

- rapid publication on acceptance

- support for research data, including large and complex data types

- gold Open Access which fosters wider collaboration and increased citations

- maximum visibility for your research: over $100 \mathrm{M}$ website views per year

At BMC, research is always in progress.

Learn more biomedcentral.com/submissions 